\title{
Alpha-bungarotoxin binding in cat carotid body
}

\author{
B. DINGER, C. GONZALEZ, K. YOSHIZAKI and S. FIDONE*
}

Department of Physiology, University of Utah College of Medicine, 410 Chipeta Way, Salt Lake City, Utah 84108 (U.S.A.)

(Accepted August 21st, 1980)

Key words: alpha-bungarotoxin - carotid body — chemosensation

The carotid body is an arterial chemosensory organ which detects changes in blood gas tensions and $\mathrm{pH}$, and reflexly contributes to the cardiorespiratory adjustments which occur during hypoxia, hypercapnia and acidosis. However, the sensory mechanisms involved in carotid chemoreception remain to be elucidated.

Morphologically, the carotid body consists of an association of elemental units, or glomeruli, within a connective tissue stroma penetrated by a dense capillary net ${ }^{5}$. The glomeruli are comprised of catecholamine-rich type I, or chief cells, which are enveloped by glial-like processes of type II, or sustentacular, cells $\mathbf{s}^{\mathbf{3}, 4,19}$. Sensory fibers from the carotid sinus nerve penetrate the glomeruli to terminate in synaptic-like apposition on type I cells ${ }^{6,18,21}$.

Schweitzer and Wright ${ }^{25}$ first noted the stimulatory effects of acetylcholine (ACh) on carotid chemoreflexes in the cat, and suggested that this substance might be involved in the generation of chemosensory activity. Later experiments characterized in detail the excitatory potency of $\mathrm{ACh}$ and nicotinic agonists on the chemoreceptor discharge from the cat carotid body $7,9,10,24$. They showed that cholinergic antagonists abolish the sensitivity to $\mathrm{ACh}$ and reduce the response to natural stimulation. More recently, it has been demonstrated that chemically identifiable ACh is present in the parenchymal tissue of the cat carotid body, rather than in the fibers or terminals of the carotid sinus nerve11,13,15. Although the site(s) of ACh storage in this tissue has not been firmly established, a high affinity component of choline uptake has been autoradiographically localized to the type I cells ${ }^{12}$. Finally, there is evidence that $\mathrm{ACh}$ is released from the carotid body during natural stimulation ${ }^{8,9}$. One interpretation of these findings is that $\mathrm{ACh}$ is a sensory transmitter in the cat carotid body, and that as such, this substance is released from the type I cells by natural stimulation to activate nicotinic receptors on neighboring sensory nerve terminals, thereby leading to the initiation of chemosensory impulses in the carotid sinus nerve ${ }^{10}$. Other recent studies have shown, however, that ACh directly depolarizes the type I cells in both normal and de-

\footnotetext{
* To whom correspondence should be addressed.
} 
nervated carotid bodies ${ }^{14}$, and that cholinergic antagonists depress the release of dopamine from these cells ${ }^{16}$. These data raise the question of whether ACh acts on the nerve terminals directly, and/or through a mechanism which involves ACh-induced release of catecholamines or other substances from the type I cells. In an effort to resolve this issue, we have attemped in the present study to localize nicotinic receptors in the cat carotid body using labelled $\alpha$-bungarotoxin $\left(\left[{ }^{125} \mathrm{I}\right] \alpha\right.$-BGT). The results will show that most, if not all, specific $\alpha$-BGT binding sites in this organ are located on non-neural glomerular elements, presumably on the type I cells.

Carotid bodies were removed from pentobarbital-anesthetized cats, placed in a lucite chamber filled with $\mathrm{O}_{2}$-equilibrated, modified-Tyrode's solution (in $\mathrm{mM}: \mathrm{NaCl}$, $112 ; \mathrm{KCl}, 4.7 ; \mathrm{CaCl}_{2}, 2.2 ; \mathrm{MgCl}_{2}, 1.1$; sodium glutamate, $42 ; \mathrm{HEPES}, 5 ; \mathrm{pH} 7.43$ at $37^{\circ} \mathrm{C}$ ) and cleaned of surrounding connective tissue with the aid of a dissecting stereomicroscope. To distinguish between total and non-specific $\alpha$-BGT binding, carotid bodies were divided into two groups prior to incubation with the radiolabelled ligand. The tissues were first preincubated for $20 \mathrm{~min}$ in a water bath shaker at $37^{\circ} \mathrm{C}$ in the presence or absence of D-tubocurarine $\left(10^{-3}-10^{-6} \mathrm{M}\right.$; Sigma $)$, or ACh $\left(10^{-3}-10^{-6} \mathrm{M}\right.$; Sigma) plus eserine $\left(10^{-5} \mathrm{M}\right.$; Sigma). The preincubation vials contained $1.5 \mathrm{ml}$ of $\mathrm{O}_{2}-\mathrm{Tyr}-$ ode's medium plus $1 \%$ bovine serum albumin. [ $\left.{ }^{125} \mathrm{I}\right] \alpha-\mathrm{BGT}(138 \mathrm{Ci} / \mathrm{mM}$, New England Nuclear) was then added to each vial to reach a final concentration of $1-40 \mathrm{nM}$, and the incubation period with the ligand was continued for $30 \mathrm{~min}$ at $37^{\circ} \mathrm{C}$. The tissues were then removed from the vials and washed for $1 \mathrm{~h}$ in $10 \mathrm{ml}$ of ice-cold $\mathrm{O}_{2}-\mathrm{Tyr}-$ ode's solution. Tissue samples for biochemical analysis were placed in glass scintillation vials and digested for $4 \mathrm{~h}$ at $60^{\circ} \mathrm{C}$ in a mixture of $200 \mu \mathrm{l} \mathrm{NCS} \mathrm{(Amersham)} \mathrm{and} 50$ $\mu 1$ water. Prior to counting in a liquid scintillation spectrometer (Packard 3385), the digestion mixture was neutralized with $750 \mu \mathrm{l}$ of acetic acid $(1.3 \%)$, and then $15 \mathrm{ml}$ of counting cocktail (PCS II, Amersham) were added to each vial. Tissue samples for autoradiography were removed from the wash media, immersed in a $0.1 \mathrm{M}$ phosphatebuffered fixative ( $\mathrm{pH} 7.6$ ) containing $1 \%$ glutaraldehyde, $1 \%$ paraformaldehyde and $0.01 \mathrm{M} \mathrm{CaCl}_{2}$, and then post-fixed in a buffered $2 \%$ osmic acid solution, dehydrated in ethanol, and embedded in Epon. Semithin sections were cut, mounted on glass slides and coated with Kodak NTB-2 emulsion using a constant rate withdrawal apparatus ( $48 \mathrm{~mm} / \mathrm{min}$ ). Autoradiographs were exposed for 6-7 weeks, developed in Dektol, and stained with methylene blue. In some animals, carotid bodies were denervated by transection of the carotid sinus nerve 12-15 days prior to removal of the organs for experimentation.

The binding of $\left.{ }^{[125} \mathrm{I}\right] \alpha$-BGT in the cat carotid body was concentration-dependent, and the amount of specific toxin binding, defined as the binding displaceable by ACh of D-tubocurarine, was maximal at a toxin concentration of $11 \mathrm{nM}(6.44 \pm 0.28$ $\mathrm{fmol} / \mathrm{mg}$ tissue, $\mathrm{n}=22$ carotid bodies). At this concentration, specific binding of [125I] $\alpha$-BGT was linear for approximately $20 \mathrm{~min}$, and then rapidly plateaued so that after 30 min little or no additional specific binding took place. Nearly all of the toxin binding could be prevented in the presence of $10^{-3} \mathrm{M} \mathrm{ACh}(91 \%)$ or $10^{-3} \mathrm{M}$ D-tubocurarine $(90 \%)$, and consequently our data suggest that most $\alpha$-BGT binding sites in cat carotid body are nicotinic receptor sites. 

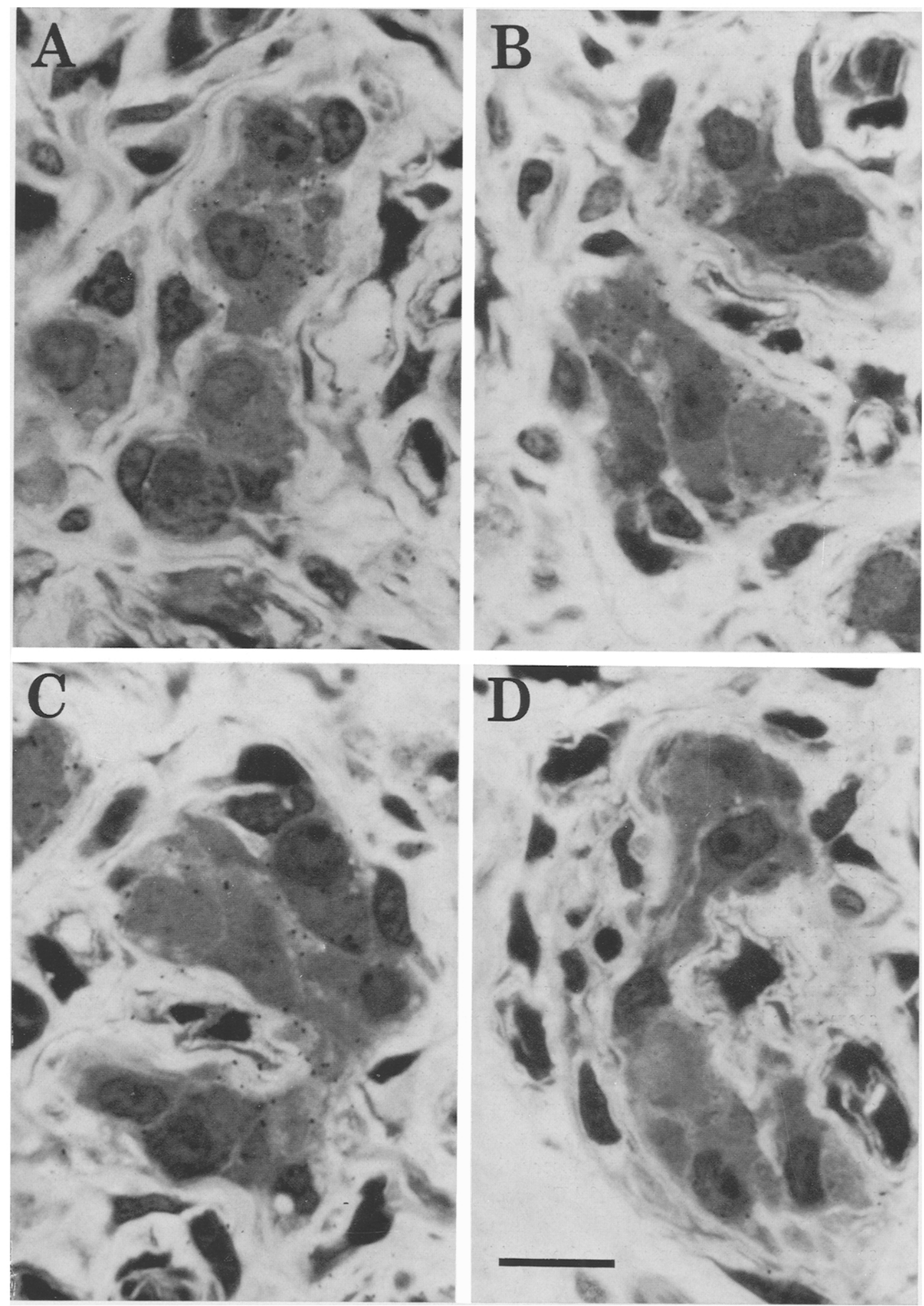

Fig. 1. Binding of $\left[{ }^{125} \mathrm{I}\right] a-\mathrm{BGT}$ in normally innervated cat carotid body. Concentration of $\left.{ }^{125} \mathrm{I}\right] a-$ BGT, $11 \mathrm{nM}$; incubation time, $30 \mathrm{~min}$. A-C: total binding. D: non-specific binding in the presence of $\mathrm{ACh}\left(10^{-3} \mathrm{M}\right)$ plus eserine $\left(10^{-5} \mathrm{M}\right)$. Note loss of specific binding from glomerular structures. Scale: $5 \mu \mathrm{m}$. 
Light microscope autoradiography of cat carotid bodies incubated with [ $\left.{ }^{125} I\right] \alpha-$ BGT demonstrated that the specific toxin binding sites are localized primarily within the glomerular apparatus. This is shown in Fig. 1, which compares total toxin binding (Fig. 1A-C) with the binding which remains (Fig. 1D) in the presence of $\mathrm{ACh}\left(10^{-3} \mathrm{M}\right)$ plus eserine $\left(10^{-5} \mathrm{M}\right)$. Silver grains are evident in association with type $\mathrm{I}$, and perhaps also type II, cells.

Biochemical and autoradiographic analysis of [125I] $\alpha$-BGT binding in denervated cat carotid bodies indicated that the localization and amount of specific biring (6.33 $\pm 0.56 \mathrm{fmol} / \mathrm{mg}$ tissue, $\mathrm{n}=17$ carotid bodies) was not significantly different from control specimens $(P>0.1)$. However, total toxin binding was increased by $56 \%(P<$ $0.01)$ in the denervated organs. The reason for this increase in non-specific binding is unknown, but may be related to the hypertrophy of type II cell processes ${ }^{17,20,21}$ and/or to the proliferation of Schwann cell elements ${ }^{1}$ consequent to the degeneration of the carotid sinus nerve.

Fig. $2 \mathrm{~A}-\mathrm{C}$ shows $\left[{ }^{125} \mathrm{I}\right] \alpha$-BGT binding in a denervated cat carotid body, while Fig. 2D shows the toxin binding which remains in the presence of $\mathrm{ACh}\left(10^{-3} \mathrm{M}\right)$ plus eserine $\left(10^{-5} \mathrm{M}\right)$. The same pattern of localization and displacement of binding sites seen in the normally-innervated carotid body is evident in the denervated organ; the silver grains appear concentrated over clusters of glomerular cells.

In summary, our results show that $\left[{ }^{125} \mathrm{I}\right] \alpha-\mathrm{BGT}$ binding sites, displaceable by $\mathrm{ACh}$ or D-tubocurarine, are located within the glomerular apparatus of the cat carotid body. Furthermore, following degeneration of the carotid sinus nerve the amount of this displaceable or specific binding is unchanged, although total binding in the denervated organ is significantly increased. These data demonstrate, therefore, that specific $\alpha$-BGT binding sites are confined primarily to non-neural glomerular elements in the cat carotid body, and hence are absent from the sensory terminals of the carotid sinus nerve. Germane to our findings, however, are the recent observations that blockade of curare-displaceable $\alpha$-BGT binding sites on chick sympathetic neurons does not affect the cholinergic-synaptic potential or the response to exogenous ACh recorded from these cells ${ }^{2}$. These observations have been interpreted to mean that $\alpha$ BGT binding sites in this tissue are not equivalent to neuronal ACh receptors. Preliminary experiments in our laboratory, however, have demonstrated that in cat carotid body $\alpha$-BGT blocks the increase in chemosensory discharge and the release of dopamine elicited by nicotine $\left(10^{-5} \mathrm{M}\right)$. Since the actions of ACh in cat carotid body seem to be largely nicotinic ${ }^{22,23}$, the apparent absence of $\alpha$-BGT binding sites on the sensory nerve endings suggests that another glomerular element, the type I or type II cell, may be involved in mediating the excitatory effects of ACh on chemosensory activity. The available evidence would implicate the type I cells in this capacity, because cholinergic agonists and antagonists alter dopamine release from both normal and denervated cat (unpublished observations) and rat ${ }^{16}$ carotid bodies, and therefore point to the likely presence of $\mathrm{ACh}$ receptors on these catecholamine-containing cells. However, the mechanisms linking these ACh receptors with excitation of chemosensory nerve fibers remain to be elucidated. 

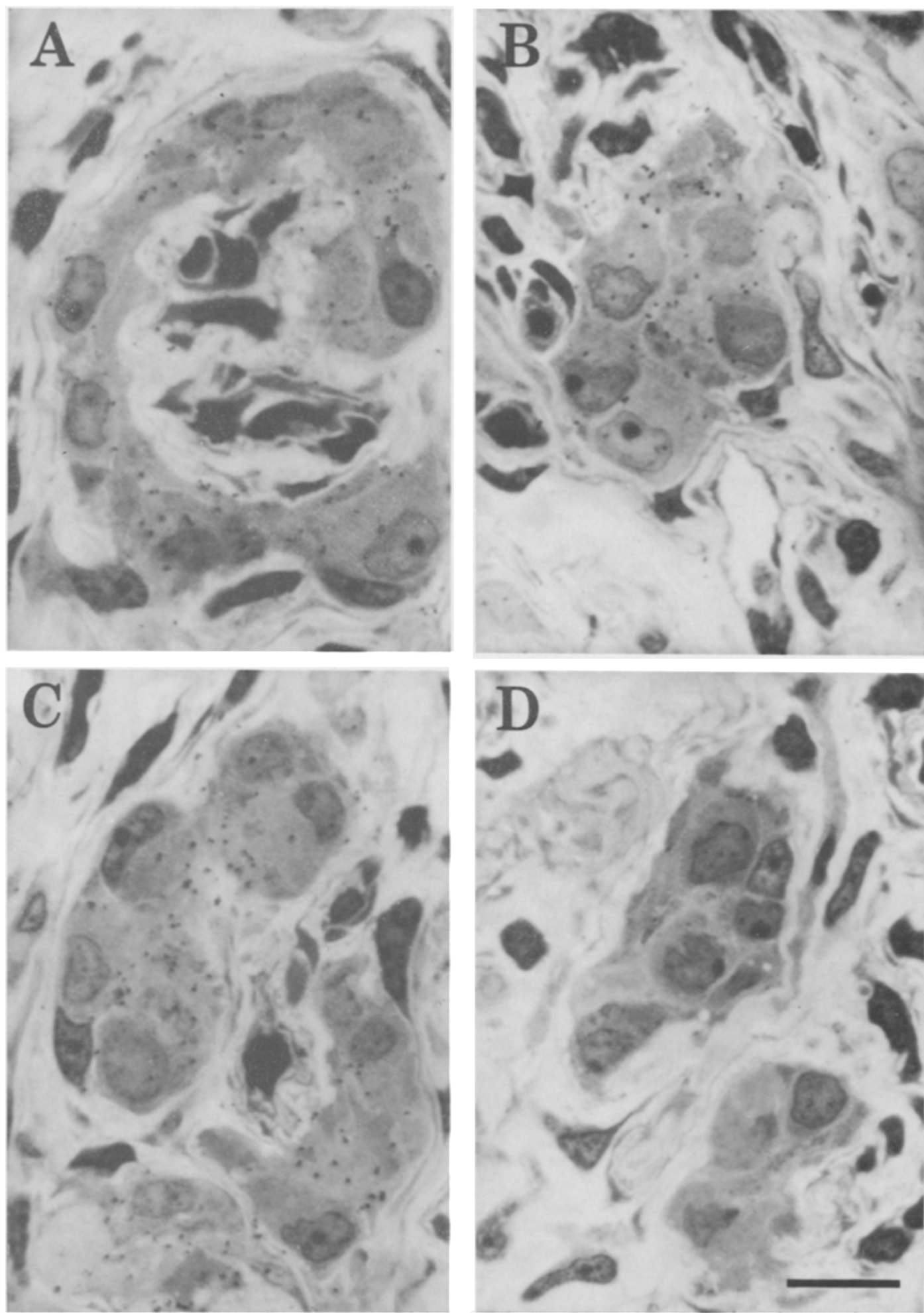

Fig. 2. Binding of $\left[{ }^{125} \mathrm{I}\right] \alpha-\mathrm{BGT}$ in chronically denervated (transection of carotid sinus nerve) cat carotid body. Concentration of $\left.{ }^{125} \mathrm{I}\right] \alpha-\mathrm{BGT}, 11 \mathrm{nM}$; incubation time, $30 \mathrm{~min}$. A-C: total binding. D : nonspecific binding in the presence of $\mathrm{ACh}\left(10^{-3} \mathrm{M}\right)$ plus eserine $\left(10^{-5} \mathrm{M}\right)$. Note similar distribution of specific binding as in normally innervated cat carotid body (Fig. 1). Scale: $5 \mu \mathrm{m}$. 
This work was supported by Public Health Service Grants NS 12636 and NS 07938.

1 Aguayo, J., Epps, J., Charron, L. and Bray, G. M., Multi-potentiality of Schwann cells in crossanastomosed and grafted myelinated and unmyelinated nerves: quantitative microscopy and radioautography, Brain Research, 104 (1976) 1-20.

2 Carbonetto, S. T., Fambrough, D. M. and Muller, K. J., Non-equivalence of $\alpha$-bungarotoxin receptors and acetylcholine receptors in chick sympathetic neurons, Proc. nat. Acad. Sci. (Wash.), 75 (1978) 1016-1020.

3 Chiocchio, S. R., Biscardi, A. M. and Tramezzani, J. H., Catecholamines in the carotid body of the cat, Nature (Lond.), 212 (1966) 834-835.

4 Dearnaley, D. P., Fillenz, M. and Woods, R. I., The identification of dopamine in the rabbit's carotid body, Proc. roy. Soc. B, 170 (1968) 195-203.

5 de Castro, F., Sur la structure et l'innervation de la glande intercarotidienne (glomus caroticum) de l'homme et des mammifères, et sur un nouveau système d'innervation autonome du nerf glossopharyngien. Etudes anatomiques et ex périmentales, Trab. Lab. Invest. biol. Univ. Madr., 24 (1926) 365-432.

6 de Castro, F., Nuevas observaciones sobre a inervación de la región carotidea. Los quimio-y presso-receptores. Trab. Inst. Cajal Invest. biol., 32 (1940) 297-384.

7 Eyzaguirre, C. and Koyano, H., Effects of some pharmacological agents on chemoreceptor discharges, J. Physiol. (Lond.), 178 (1965) 410-437.

8 Eyzaguirre, C., Koyano, H. and Taylor, J. R., Presence of acetylcholine and transmitter release from carotid body chemoreceptors, J. Physiol. (Lond.), 178 (1965) 463-476.

9 Eyzaguirre, C. and Zapata, P., The release of acetylcholine from carotid body tissues. Further study of the effects of acetylcholine and cholinergic blocking agents on the chemosensory discharge, J. Physiol. (Lond.), 195 (1968) 589-607.

10 Eyzaguirre, C. and Zapata, P., A discussion of possible transmitter or generator substances in carotid body chemoreceptors. In R.W. Torrance (Ed), Arterial Chemoreceptors, Blackwell, Oxford, 1968, pp. 213-247.

11 Fidone, S., Weintraub, S. and Stavinoha, W., Acetylcholine content of normal and denervated cat carotid bodies measured by pyrolysis gas chromatography/mass fragmentometry, J. Neurochem., 26 (1976) 1047-1049.

12 Fidone, S., Weintraub, S., Stavinoha, W., Stirling, C. and Jones, L., Endogenous acetylcholine levels in cat carotid body and the autoradiographic localization of a high affinity component of choline uptake. In H. Acker, S. Fidone, D. Pallot, C. Eyzaguirre, D. Lübbers and R. Torrance (Eds.), Function and Functional Significance of the Carotid Body, Springer, 1977, pp. 106-113.

13 Goldberg, A., Lentz, A. and Fitzgerald, R., Neurotransmitter mechanisms in the carotid body: absence of ACh in the carotid sinus nerve, Brain Research, 140 (1978) 374-377.

14 Hayashida, Y. and Eyzaguirre, C., Voltage noise of carotid body type I cells, Brain Research, 167 (1979) 189-194.

15 Hellstrom, S., Putative neurotransmitters in the carotid body. Mass fragmentographic studies. In E. Costa and G.L. Gessa (Eds.), Advances in Biochemical Psychopharmacology, Vol. 16, Raven Press, New York, 1977, pp. 256-263.

16 Hellstrom, S., Hanbauer, I and Costa, E., Selective decrease in dopamine content in rat carotid body during exposure to hypoxic conditions, Brain Research, 118 (1976) 352-355.

17 Hess, A., Chronically denervated rat carotid bodies, Acta anat. (Basel), 97 (1977) 307-316.

18 Hess, A., Electron microscopic observations of normal and experimental cat carotid bodies. In R. W. Torrance (Ed), Arterial Chemoreceptors, Blackwell, Oxford, 1968, pp. 51-56.

19 Lever, J. D., Lewis, P. R. and Boyd, J. D., Observations on the fine structure and histochemistry of the carotid body in the cat and rabbit, J. Anat. (Lond.), 93 (1959) 478-490.

20 McDonald, D. M., Peripheral Chemoreceptors: Structure-function relationships of the carotid body. In C. Lenfant (Ed), The Lung Biology in Health and Disease, Vol. X, The Regulation of Breathing, Marcel Dekker, in press.

21 McDonald, D. M. and Mitchell, R. A., The innervation of the glomus cells, ganglion cells and blood vessels in the rat carotid body: a quantitative ultrastructural analysis, J. Neurocytol., 4 (1975) 177-230. 
22 McQueen, D. S., Effects of suberyldicholine on carotid baroreceptors and chemoreceptors, Neuropharmacology, 13 (1974) 829-835.

23 Monti-Bloch, L. and Eyzaguirre, C., A comparative physiological and pharmacological study of cat and rabbit carotid body chemoreceptors, Brain Research, in press.

$24 \mathrm{Nishi,} \mathrm{K}$. and Eyzaguirre, C., The action of some cholinergic blockers on carotid body chemoreceptors in vivo, Brain Research, 33 (1971) 37-56.

25 Schweitzer, A. and Wright, S., Action of piostigmine and acetylcholine on respiration, Quart. J. exp. Physiol., 28 (1938) 33-37. 